\title{
Building events in inner-city Gdansk, Poland: exploring the socio-spatial construction of agency in built form ${ }^{1}$
}

\author{
By Stefan Bouzarovski. s.bouzarovski@gmail.com
}

\begin{abstract}
This paper explores the ways in which buildings interact with the social fabric of everyday life. Its main argument is that agency is in the built environment is practised and performed through a dynamic relation between households and the built fabric, among other actants. The paper is based on an ethnographic study of 42 inner-city households in the Polish city of Gdańsk, combined with archival research. It investigates the forces that constrain and enable the transformation of residential dwellings over time, with the aid of Jane Jacobs' concept of 'building events'. I wish to provide a more elaborate theorisation and operationalisation of the building event, while applying it to the interrogation of relations between buildings and households in the given context. The article interrogates the different modalities through which buildings have been forced to create new allies and associations - allowing for the interpretive flexibility of their technological frame - in order to keep surviving and functioning in different socio-political circumstances.
\end{abstract}

\footnotetext{
${ }^{1}$ A later version of this paper has been published as: Bouzarovski S (2009) Building events in inner-city Gdańsk, Poland: Exploring the socio-spatial construction of agency in built form. Environment and Planning D: Society and Space 27: 840-858.
} 
'She felt the hairs begin to stir on the back of her neck, and she became of the whole of the building around her, the corridors dark, the machines idling, various experiments running automatically, computers monitoring tests and recording the results, the air-conditioning sampling and adjusting the humidity of the temperature, all the ducts and paperwork and cabling that were the arteries and the nerves of the building awake and alert ... almost conscious, in fact' (Pullman, 2007, page 247).

\section{Introduction}

Koolhaas (1998) points to 'an inherent paradox with regard to architecture's interest in flow', because 'architecture fixes or attempts to define a moment', while 'flow moves' (page 94). Thus, architects are like 'King Midas in reverse', because their tendency to 'freeze time' in the built environment usually leads to the death of the subject they are interested in (page 95). Although this statement was given at a conference on future developments in architecture, its implications also extend to the discipline's theoretical past and present: in discussing the ability of architects to encode particular temporal topologies and institutional arrangements in the built form, Koolhas has connected the (im)mutability of buildings with broader debates about the relationship between power and architecture, featured in the work of authors such as Bourdieu (1989; 1990), King (1996), Haynen (2001), Vidler (2001), and Boyer (1986).

The co-embodiments and co-expressions of power between social and built actants form the central theme of this paper. However, instead of looking at the embeddedness of the architectural design process in different forms of power - a relatively well-researched subject - I am more interested in the multiple ways in which buildings interact with the social fabric of everyday life. In order to achieve this, I explore the forces that constrain and enable the transformation of residential dwellings over time, via a diachronic study of collective apartment buildings in two inner-city districts of Gdańsk, Poland. My main argument is that the agency of built form at the level of everyday life is not only 'structured and shaped by walls, doors and windows, framed by the decisions of designers' (Dovey, 1999, page 1), but rather, is co-produced through the networked relations between animate (households, individuals) and inanimate (buildings, dwellings) objects, among other actants. In other words, socio-spatial agency at this scale is not something that is physically possessed or 'stored' by either buildings or people. Instead, it is practised and performed through a dynamic relation between households and the built fabric: it is 'an action, an event, a way of being' (Doel, 2000, page 125).

In framing my main argument in this way, I wish to address a theoretical gap between the mainstream understandings of the production of urban built landscapes, on one hand, and the spaces of everyday life, on the other. Goss' (1988) call for the development of an 'invigorated architectural geography', premised on the notion that buildings impart meaning and character to the space in which they are located (page 402) has not been adequately answered in studies of household mobility and consumption patterns. While recent years have seen a significant body of work on the performed and practised aspects of architecture (see Eisenman, 1992; Jacobs, 2006; Jenkins, 2002; Imrie, 2003; Lees, 2001; Llewelyn, 2003; 2004; Kwinter, 2001; Tschumi, 2000; 2005), which draw, in part, from insights borrowed from nonrepresentational theory (see Latham and McCormack, 2004; Lorimer, 2005; Smith, 2003; Whatmore, 2002; Merriman et al, in press), a conceptual framework that would 
connect everyday life with the materialisation of power in built form has yet to be developed.

Jacobs' (2006) concept of 'building events', premised on the Latourian notion of 'place event' - seen as 'a unique assemblage of acts of timing and spacing which work to bring the house-thing into being (or not)' (page 26) - is a key starting point of my attempt to develop such a framework. I wish to provide a more elaborate theorisation and operationalisation of the building event, while applying it to the interrogation of relations between buildings and households in the given context. In order to achieve this, I rely on Bingham's (1996) argument that buildings - among other things and people - can 'be seen as (potentially) embodying networks, and thus (potentially) the loci of "action"" (page 647). The paper thus operates with a range of concepts stemming from the sociology of technology and science (STS) and actornetwork theory (ANT), which see agency as an 'effect generated by a network of heterogeneous, interacting, materials' (Law 1992, quoted in Bingham, 1996, page 647). In particular, I focus on the different ways in which buildings have to harness allies in order to be formed and to function over time (Jacobs, 2006). The paper examines how the development of such a particular 'technological frame' (Bijker, 1987) between people and buildings is being practiced to their benefit and/or detriment.

\section{Spatial and methodological framework of the study}

Much of the evidence cited in this paper is based on a field study of the domestic spaces, housing histories, residential aspirations and everyday lives of 42 households in two inner-city districts of the Polish city of Gdańsk, undertaken between February 2006 and April 2007. The households were surveyed with the aid of semi-structured interviews that included questions about their housing careers and aspirations, daily mobility patterns and perceptions of the built environment, as well as a broader investigation of the architectural and social fabric of their residential dwellings, buildings and neighbourhoods ${ }^{2}$. The interviews were tape-recorded and later transcribed, with information about the built materials, architectural design, room layouts and residential functions of the dwellings and buildings being entered in a purposely-designed diary. The research took place in the homes of local residents who were approached on a random basis - mainly through informal networks - but with the aim of encompassing the widest possible range of housing and demographic situations. I also relied on a range of secondary sources, including archival materials, literatures in the local language, and policy reports.

Gdańsk is a complex, multi-layered Baltic metropolis with a varied urban structure and rich history. At its centre lies a mediaeval core that is functionally connected to the port, traditionally the main source of capital and employment for the city. The city centre is surrounded by a combination of industrial uses and densely-built up quarters with tenement buildings mainly dating from the nineteenth and early twentieth centuries. This paper is focussed on two such neighbourhoods: the formerly workingclass district of Nowy Port that lies adjacent to Gdańsk's northern waterfront, and the inner-city quarter of Wrzeszcz Dolny to the west of the urban core. Both areas,

\footnotetext{
${ }^{2}$ Not all interviews have been cited in this paper; the names of households mentioned in the text have been changed for privacy reasons. Those starting with ' $\mathrm{W}$ ' were interviewed in Wrzeszcz, while ' $\mathrm{N}$ ' is for the respondents in Nowy Port. The interviews were part of a wider study, the main results of which are reported in Buzar and Grabkowska, 2008.
} 
otherwise well known for their pivotal role in the events that led to the outbreak of World War II and the fall of Communism, have underwent major social and spatial changes over the last six decades. As a result, they contain three types of collective apartment buildings: nineteenth to early twentieth tenement blocks of varying size and structure in Wrzeszcz Dolny (where the majority of buildings have more than three floors); terraced blocks, mainly less than three storeys high, constructed in Nowy Port before World War II, as well as a 1970s eight-storey prefabricated panel housing estate in Nowy Port.

The paper shifts between scales when exploring building events in this housing stock: although information about the weaving of different social and technical networks around individual dwellings is derived mainly from household interviews, archival information and building plans, the examination of the reasons for their creation and destruction is placed within the wider context of neighbourhood change in the two districts. Rather than developing a narrative around any individual building, the paper treats the apartment blocks in this part of the city as a collective entity, providing a joint account of the types of issues that they have faced. While this approach does bring with it the inherent dangers of generalisation, it can also potentially capture the formation and destruction of heterogeneous assemblages in a more powerful way, considering that all of the interviewed households reside in one of the three building types described above.

\section{The building event conceptualised: diagrams of power in architectural tissues}

When thinking about the power geometries and topologies of the built environment, it is impossible to omit Goss' (1988) seminal work on the issue, which was motivated by geography's failure 'to come to terms with the complexity of architectural form and meaning' (page 392). Having identified at least three ways in which the spatial configuration of the built environment incorporates economic, political, and ideological dimensions - whereby buildings can be seen either as objects of value, signs, or spatial systems - he points out that 'space can no longer be conceived as merely material, nor social relations as merely abstract' (page 402). Although few geographers have followed up these ideas in a comprehensive manner (but see Jacobs, 2006; Llewellyn, 2004), it is worth noting Lawrence and Low's (1990) anthropological perspective on the issue, which points out that analyses and interpretations of building decisions must be placed within the context of social and economic forces that continuously influence actors.

The relationship between housing structures and behaviours, on the one hand, and cultural, social and economic norms, on the other, has been explored within various geographical and thematic contexts. For example, Ozaki and Lewis's (2006) research of Japanese house plans examined how 'the social classifications that distinguish inside from outside' produce boundaries that 'leave their trace at the phenomenological level' (page 101). Earlier work by authors such as Hiller and Hanson (1984), Marcus (1993), King (1980) and Sommer (1983), has also, through various theoretical perspectives, interrogated the ability of buildings to reinforce and reproduce power structures in society. However, much of this literature can be critiqued for conceptualising the architect-building-household relationship via a profoundly uni-directional and instrumentalised lens. Rather than being an active part of the construction of everyday life, the built environment tends to be treated merely as container or conduit of the agency vested in it by architects - a view of power 
typical for theorists like Mann (1993), Weber (1984), and even Giddens (1984). The social-constructivist perspective that dominates this line of work has failed to grasp the dynamic ways in which buildings and people 'are always already bound together, always already binding together' (Bingham, 1996, page 635).

Part of these shortfalls may be overcome by the application of Osborne and Rose's (1999) interrogation of the instruments and devices through which 'power, regulation, ethics and citizenship' have been 'spatialised' within different urban tissues. One of their main findings is that all attempts to govern existence in urban form contain an immanent set of 'diagrams that give consistency - though by no means homogeneity - to their elements' (page 758). This line of thought, it can be argued, stresses the capacity of power entanglements to 'set in train the relational encounters which are always replete with effects of power' (Sharp et al, 2000, page 24). It enriches the study of urban architectural evolution with the diagrammatic thinking of authors like Foucault and Deleuze, 'where power is seen to constitute its own organization yet produce itself relationally from point to point' (Allen 2003, page 7), thus allowing architecture to be 'conceived as text in the process of being created or produced' (original emphasis, Frisby, 2001, page 19).

It can be argued that an interpretation of these ideas through a network-based approach allows the city to be seen as a 'latent principle of mutability' whose constitutive events, processes and activities are not only constantly changing in relation to each other, but also in terms of appearance, function and importance (Sheringham, 1996; but also see Tchumi, 2000; 2005). Such a conceptualisation of the articulation of agency and flow in the built environment can also lead to the creation of 'an architecture that is materially liquid, that configures and is attentive not to stability but to change and is thus at one with the fluid and shifting nature of all reality' (original emphasis, Solà-Morales 1988, page 36, but also see Deleuze and Guattari, 1988). This is where the emergence of modern urbanism 'as an extraordinary complex and dynamic sociotechnical process' (original emphasis, Graham and Marvin, 2001, page 8) becomes especially relevant, turning contemporary urban life a 'ceaseless and mobile interplay' of dynamics at different scales (ibid; but also see Thrift, 1995; 1996).

In their entirety, such literatures suggest that existing theorisations of built and social relations in the city already possess some analytical tools to explain the embodiment and performance of power in the built environment. They point to the multiple ways in which relational assemblages of human and non-human actants work together in the construction of building events, since, as emphasised by Jacobs (2006), the materiality of the building an achievement of 'a diverse network of associates and associations' (page 11). Understood through such a lens, a building is always being 'made' or 'unmade', 'always doing the work of holding together or pulling apart' (Jacobs, 2006, page 12). However, the mechanisms through which social and technical systems active in this context are socially co-constructed and imbued with agency remain unclear. A micro-level perspective, operating at the scale of everyday life, is necessary to help unravel the myriad socio-technical contingencies that interact with household behaviour in formations of the built environment.

\section{The building event operationalised: linking the technological and the social through 'functional blankness'}


The social production of technological networks is a key component of relations between buildings and people at the level of quotidian. One of the most useful explanatory frameworks for the construction of such networks has been developed by Bijker (1987), who uses the concept of 'technological frame' to explain their embeddedness in a combination of theories, tacit knowledge, engineering approaches (such as design methods and criteria), specialized testing procedures, goals, and 'handling and using practice' within any given community (page 168). Bijker and Law (1992) employ this notion, as well as ideas proposed by authors like Callon and Latour (1981), to outline some of the devices involved in 'delegating' the process of 'creating and closing an opening' to an technological artefact, in order to ensure that 'things will stay in one place once those who initiated them have gone away and started to do something else' (Bijker and Law, 1992, page 294). They argue that a central part of this process is the separation of 'inside from outside' by means of physical exclusion, shifts in materials and media, or organisational orderings. The latter includes metaphorical barriers that are inscribed in legal, organisational, discursive, or professional arrangements (page 296).

Such thinking brings us back, once again, to ANT, which insists that social, technical and natural objects should be viewed on the same terms (Callon, 1986; Latour, 2005). According to Murdoch (1998) 'it is the heterogeneity of actor-networks which allows them to remain durable in space and time', especially 'the seamless mixing of social, technical and natural objects within networks' (page 367) which helps them frame human interactions, while shaping their activities and directing their movements. By flattening the distinctions between the entities which comprise networks, and questioning the depth of differences between humans and nonhumans, ANT thus allows for a novel reading of socio-spatial relations in the built environment. Its network-orientated topology of space is congruent with a relational approach that conceives 'difference and the space that it constitutes as seemingly fluid, complex, and unfinished in character' (Hetherington and Law, 2000, page 127). Kirsch (1995), argues that, seen in this light, technology 'is always open to interpretation, resistance, and change'. The accumulation of sociotechnical processes in 'technological formations', he argues, helps redefine the boundaries of 'nature', space and time (page 536).

An extension of this argument to contemporary urban settings implies that 'the city has no completeness, no centre, no fixed parts', and should rather be seen as an 'amalgam of often disjointed processes and social heterogeneity' (Amin and Thrift, 2002, page 8). In such conditions, a critical reading of 'the power of the everyday' (ibid, page 9; but also see de Certeau, 1984; Whitehead, 2005), reaching beyond and above structure/agency dualisms, becomes crucial for understanding the multiple ways in which clashes between the different rhythms of the city could 'destabilize urban life-chances and life-styles' (Allen et al, 1999, page 4). Given that everyday life is 'mysterious, substantial and fecund', Gardiner (2000) claims that a further investigation of its hidden and suppressed potentials may reveal the foundations of 'higher' activities of human beings, including 'abstract cognition and practical objectifications' (page 168). Arguing along similar lines, Seigworth (2000) emphasises the importance of the 'banal' processual plane of quotidian, which moves 'in parallel (as side-real space) with the "actual" existence of the human everyday' (page 234). Within this context, the suggestion that humans are 'disciplined through habit' (Foucault, 1977) becomes especially important, since 'we cultivate habits, they 
are encultured' and 'we live our cultures not only through discourse, signs and meaning, but through the movements of our bodies' (Wise, 2000, page 303). Such relations may also include movement and interaction with the built spaces of the city (Jensen, 2007).

Despite their theoretical depth and richness, most of these contributions fail to explicitly address the crucial question of whether and how buildings might have agency that extends beyond their immediate design features. This issue can be explored further by drawing attention to the "conceptual and empirical inadequacy of human-centered notions of agency', while foregrounding a more distributed, nonlinear and non-hierarchical understanding of the concept, one that crosses the "humannonhuman divide' (Bennett 2005, page 446). Such work points to the multiple mechanisms that allow humans and non-humans to inhabit co-constructed 'force fields' or 'assemblages', which have a synergetic agency of their own, while pulsing with different internal energies (Bennett, 2004; 2005; Latour, 2005).

As far as the particular agency of buildings is concerned, it may be helpful to turn to Hetherington (1997), Brown and Capdevila (1999) and Hetherington and Lee's (1999) reading of the agentic capabilities of material artefacts. According to this set of theories, material actants exercise a specific form of agency, which despite being devoid of intentionality, is able to attract inscriptions of networks upon them. This can be attributed to an object's 'functional blankness', whereby what it 'fails to say ... forces the network to fold itself around the object in innumerable different ways', in order to accommodate the disruption created by its semiotic silence (Brown and Capdevilla, 1999, page 40). Thus, the lack, rather than the possession, of meaning prompts the 'plaiting of weak ties' (Latour, 1998) around a material artefact, in an effort to connect and order. It is often pointed out that humans also perform their own functional blankness, since it is precisely 'when we fail to speak or act according to the programmatic directions of the networks in which we are embedded that our “agency" shines through most self-evidently" (Brown and Capdevilla, 1999, page 40).

Such a reading of agency suggests a radically different interpretation of will and intentionality, which can be also extended to the performance and practice of architecture in everyday life (see Jacobs and Smith, 2008). In the case of the relationship between buildings and people, this understanding can provide a first step towards a household-level application of Jacobs' (2006) claim that 'the building thing is not a passive context, nor even a fully determining parameter, for the resident/user' (page 12) in the context of household behaviour. It also points to the one of ways in which we may start to operationalise building events in this setting: the notion of 'functional blankness' opens the door for interrogating the relations that allow built forms to be implicated in the weaving of socio-technical webs between households and the architectural fabric. This concept connects the technological frames embodied in different building designs with the articulation of everyday life in the home.

\section{The pre-war period in Gdańsk: setting the technological frame}

Building events in Wrzeszcz and Nowy Port are intimately linked with the historical development of Gdańsk. This city acted as the principal port in this part of the Baltic sea ever since the days of the Hanseatic league in the fifteenth century (Tölle, 2008). The economic prosperity, population mobility and access to major trading routes associated with the port greatly benefited the development of the two districts. The 
building materials, economic capital and institutional regulations that were implicated in their construction originated not only from the wider Pomeranian region of which Gdańsk is the capital, but the Baltic Sea, Poland and other parts of Europe more broadly. The Gdańsk urban area also acted as a powerful population gravity centre, bringing in both working-class households from the surrounding areas as well as wealthier bourgeois families from further afield. They created the population pressure and housing demand that led to the expansion of building activities in Wrzeszcz and Nowy Port, as well as their incoporation into the city of Gdańsk.

Wrzeszcz itself was a prosperous suburban vilage until the second half of the eighteenth century, when it was connected to the Gdańsk via a four-lane paved road, lined with trees imported from the Netherlands. This, together with its administrative inclusion into Gdańsk in 1807, marked the beginning of the district's rapid urban social transformation: it attracted both prosperous residents and workers who were employed in local breweries, distilleries and retail. A clear spatial division began to emerge within the district, whereby its southern part (also known as Gorny, or 'Upper' Wrzeszcz) became dominated by luxurious villas and terraced blocks, while the northern section (Dolny, or 'Lower' Wrzeszcz) mainly contained collective working-class housing (Orłowicz, 1921; Samp, 1992; Stankiewicz and Szremer, 1959). The main transportation axis - consisting of a road and railway track - formed a clear-cut boundary between these two zones (Rada Miasta Gdańska, 2005).

The first historical references about Nowy Port can be traced back to the thirteenth century, when it was a fishing village at the mouth of the Vistula river. The settlement began to expand under Prussian rule, following the excavation of a new river canal ('Neufahrwasser') in 1675. Following a change in the river's course in 1840, the canal was further expanded and dredged, increasing the area's importance in facilitating access to the port. The development of Nowy Port received a further boost in 1867, thanks to the construction of a train line connecting its centre to the main railway station in Gdańsk. Inhabited mostly by seamen and workers from the large industrial plants situated by the river, the area flourished in the 1920s and 1930s, attracting as many as 30,000 tourists per year due to its seaside location. Most of Nowy Port's richly-ornamented Secession-style tenement buildings date from this era; they were constructed right next to the old fishermens' houses.

Seen through the lens of technological frames, the built stocks of tenement buildings in both Nowy Port and Wrzeszcz Dolny were the product of a specific amalgamation of economic and political interests, design approaches and planning paradigms that brought together people and materials from across Poland and the Baltic region. In their entirety, these networks of forces and 'things' transformed two quiet rural settlements into thriving urban neighbourhoods. At the moment of their creation ranging from the mid nineteenth to the early twentieth century - the buildings harnessed a wide range of allies to aid their existence, ranging from the city authorities to the local workers and fishermen who benefited from the economic prosperity and development of the two areas. Thanks to this assemblage of interests, the two neighbourhoods and their built stocks survived and flourished well into the twentieth century.

\section{World War II and after: new conditions, new allies}


World War II disrupted the intricate tapestry of material and social networks that had sustained the progress of Wrzeszcz Dolny and Nowy Port, placing their built stock in a new set of political and economic circumstances. Although the two neighbourhoods largely avoided the war destruction that devastated most of Gdańsk, many buildings were nonetheless heavily damaged by the intense fighting. A further dramatic shift was brought about by the alteration of the city's ethnic structure, as its 350,000 strong ethnic German population either emigrated, was expelled or murdered, while being replaced with about 150,000 ethnic Poles (Tölle, 2008). This was accompanied by a major change in the city's political regime, which saw the establishment of central planning and Communist party rule, governed by Soviet political ideologies. The new set of conditions meant that tenement buildings in Nowy Port and Wrzeszcz Dolny had to create a whole new set of allies and networks that allowed their technological frame to survive in a radically different socio-economic environment.

The process that 'displaced' residential buildings from their established networks and created a disruption warranting the formation of new hybrid entanglements was entirely temporal. It was the movement from one type of economic-political setting to another that allowed buildings to change their 'conditions of possibility', and extend their 'network statements and translations' (Hinchliffe, 2000, page 224) across space. Their functional blankness forced social and material actants to form new heterogeneous assemblages, due to, among other contingencies, the new set of circumstances in the housing market and changing relations of economic production.

Our interviews indicated that interpretive flexibility in this context was mainly articulated via different types of non-market transactions. For example, illegal squatting allowed residential buildings to create linkages the new population of the city, prompting the emergence of new building events. Having been badly damaged by the Red Army, many tenement blocks in Nowy Port and Wrzeszcz were spontaneously inhabited by displaced families who arrived in Gdańsk from territories further East and were practically homeless up to that point. The state soon became another ally of the residential buildings; faced with major housing shortages, it allocated many of the existing dwellings to the new in-migrants. The relatively large size and flexible floor plans provided a key advantage in this respect, as confirmed by Narcyz, the inhabitant of a $20^{\text {th }}$ century terraced block:

'these flats were built for German officers between the two wars, and they are very well planned and constructed. Before World War II there used to be two flats on each floor, which were subsequently halved to make room for us, but they are still very functional. In our flat we closed the door between the living room and the bedroom in order to create separate rooms for me and my mother'

However, persistent conditions of housing shortage, combined with the inefficiency of Communist central planning, meant that once they had settled in their allocated or squatted dwelling, households had very few opportunities to relocate to a new home. With formal housing transactions firmly controlled by the state, moving house through official channels normally involved cumbersome bureaucratic procedures and long waiting lists. It therefore came as little surprise that the interviewees who had managed to achieve residential mobility during Communism had done so exclusively through informal exchanges and/or barter: for example, Wanda was able to acquire 
her present 69 sq. m. apartment by swapping it for another state-assigned, but betterlocated flat in the same neighbourhood:

'under Communism, every citizen paid a monthly contribution for social housing to the state, which was recorded in a special booklet. If you were lucky enough, after some years you would get a flat "of your own". In 1985, I was allocated an apartment not very far from here; it was in a newly built building. I managed to swap it with the people who had this flat ... I liked its location - it was quite central, and close to a school and medical centre. The previous occupants were pensioners; they offered the apartment to me as didn't need so much space anymore, and were no longer fit enough to carry coal from the basement. The flat used to have a coal stove, but later I managed to install central gas heating'.

In such conditions, in-place structural alterations of the dwelling stock became the only available method for residential mobility. This meant that the buildings gradually came to host a wide range of 'alternative' and non-market building practices + . Relying on barter or gift exchanges of building materials and labour provided households with the ability to respond to a demographic event, or make the transition to a new housing episode, without moving to a new home. In response to existing household needs, the buildings enabled the creation of new heterogeneous entanglements (new domestic arrangements, new residential functions) which ultimately helped improve the households' quality of life and the buildings' durability.

The socio-economic networks constructed by the households in order to mobilise these relations stemmed from the functional blankness of the dwelling stock, whose role changed over time as a household's residential needs evolved. The historical layering of technological frames (which had produced the buildings in the first place) and interpretive flexibility (which allowed the transformation of their roles and uses) led to the emergence of multiple building events that allowed these structures to harness human and non-human allies. As pointed out by Władysław,

'when we first moved to Gdańsk in 1974, we rented a very tiny flat. Then we squatted another, slightly larger one not very far from here. After managing to resist four eviction commands, we eventually had to leave and moved here. We made a lot of changes to the apartment, even though we do not own it and never received any support from the council. At the beginning there was a shared bathroom in the staircase; we built one inside the flat by ourselves, without permission. We also installed wooden fitted cupboards in the corridor and constructed a partition wall in the living room so that the each of our children could have a space of her/his own while they were growing up. When they moved out we pulled the partition wall down'.

The widespread presence of non-market building practices under conditions of low residential mobility meant that the develoment trajectories of the two districts gradually began began to converge under Communism. Broadly speaking, both areas stagnated in demographic and economic terms as a result of persistent underinvestment and the slow out-migration of higher-income households to newly built housing estates at the outskirts of the city (Tusk, 1996). But the 1960s and 1970s 
brought about a partial reversal of these trends, thanks to the construction of a perfabricated panel housing estate with multi-storey apartment blocks in the southern part of Nowy Port. The area quickly managed to attract new migrants, as some of the newly-constructed buildings came to house more than 2000 tenants each.

As a result of the poor construction quality and the ubiquitous lack of maintenance, however, the Nowy Port housing estate also began to deteriorate very quickly. Considering that the general lack of residential mobility also applied to this part of the city as well, it is worth mentioning that most of the households who we interviewed there insisted that such buildings were less adaptable to changing household needs, compared to older tenement buildings and terraced houses. As pointed out by Nikifor, whose household had made major alterations to the home in order to add a separate room for their second daughter,

'in the socialist housing estates, which consist of prefabricated panels, it is difficult to pull down walls or change the arrangement of rooms. The older buildings are much more flexible'.

In general, the reviewed evidence indicated that the built stock of the two districts managed to survive the new set of post-World War II conditions by enrolling an entire new set of associates, consisting of new residents who moved to the area after the war, state housing authorities, as well as a wide range of building materials (mainly provisioned informally and from local sources) that helped sustain in-situ residential mobility. Building events during Communism were shaped by the manner in which older technological frames embedded and created within the built fabric allowed the environment of the home to be transformed in response to changing household needs. In this respect, there were significant differences between dwellings that were constructed in different historical periods, and according to different architectural principles. The design features of the buildings - which embodied different construction approaches, ideologies and systems - interacted with household decisions in the formulation and implementation of housing strategies.

\section{The post-Communist transformation: the built environment opens up}

The movement towards a market-based economic regulation that has been unfolding in Poland since 1989 has been marked by the implementation of neoliberal policies including liberalisation and privatisation - throughout the housing sector (Kaczmarek, 2001; Kotus, 2006; Kim, 2004; Michalski, 2006; Uchman and Adamski, 2003). At the same time, however, Polish society has become more unequal and polarised, with urban spaces undergoing trends of commercialisation, commodification, gentrification, the construction of new office space and gated communities, and the decline of working-class districts (Balcerzak-Paradowska, 2005; Kalaska, 2002; Kotus, 2005). In Nowy Port and Wrzeszcz Dolny alike, relations between buildings and people in the housing stock have been rapidly 'unlocked' from the clasp of a centralised, planned economy, becoming subject to a wide range of socio-economic transactions and spatial transformations (Kim, 2004; Mayo and Stein, 1992; MuziolWecławowicz, 2000). These developments destabilised older relations between social and built formations, warranting the creation of new networks of appropriation and survival. 
Even though the post-Communist transformation lifted the wide range of stateimposed limits on residential mobility, many households were still unable to move house due to a lack of financial capital. Therefore, in-place housing modifications continued to serve as an alternative form of residential mobility, often even intensifying as a result of the wide availability of cheap building materials. The interviews indicated that the built environment has helped energise and sustain such practices, by providing an alternative and flexible source of capital. But built alterations and improvements of the home were not the only form of non-capitalist economic production in this context: we found several cases where the physical structure and character of residential dwellings permitted the articulation of a much wider range of alternative economic practices. For example, several interviewees had converted their homes into workplaces, using the domestic domain as a base for running small enterprises, sometimes operating outside the formal economy. The dwellings quickly became enmeshed in a wider network of economic practice that allowed them to create a new set of allies beyond the immediate neighbourhood context.

In some cases, the built space of the home provided a source of rental income, thanks to changes in the internal layout of the home. Waleria, who lived in a spacious, turnof-the century apartment was subletting one of her rooms in order to supplement her modest pension. This was facilitated by the structure of the dwelling, which consisted of three interconnected rooms that were each linked to the corridor. In order to give more privacy to their then teenage son, she and her late husband had decided to seal off one of the interconnecting doors, with the aim of separating one of the rooms from the rest of the open space. The arrangement, which had been implemented more than 10 years ago, now allowed her to use her living space in a more rational way, while providing an additional source of income:

'I can't afford to live in such a large apartment at this age, and yet I don't want to move out of this district. Renting this room, albeit illegally, allows me to do that'.

In the case of this household, non-market based physical transformations of the space of the home - allowed for by the structure of the built fabric - created a source of livelihood and improved quality of life. However, there were several cases in which such relations potentially constrained the fulfilment of household needs: the sociospatial networks inscribed on the blank figure of built forms were insufficiently strong to counter older, more established assemblages. Thus, Weronika, a young professional who lived in a terraced tenement building in the centre of Wrzeszcz, made a number of interventions to her 42 square metre apartment after moving there in early 2001 (see Figure 3), having

'changed the heating, enlarged the bathroom and moved the bathroom door ... Previously it was facing the main entrance, which wasn't very convenient'.

Weronika's housing strategies were implemented in response to her specific housing needs - those of a single woman in her thirties - which did not correspond to the original function of a flat that had been originally constructed for a nineteenth-century working class family. Despite the numerous transformations, the built fabric of the apartment has limited the extent to which she could alter the function of the dwelling: 
'I would have liked to pull down the wall separating the kitchen from the bedroom, but I cannot do anything about that because there are six chimneys inside it. Three of those are for ventilation, and the other three are for the former heating system - there are two for each of the floors below me. Also, the narrowness of the entrance corridor makes it impossible to move in big pieces of furniture'.

In Weronika's case, the clash between two technological frames allowed only part of the household's present residential requirements to be met. Responding to the functional blankness of her apartment required a more intense co-weaving of networks within the grain of the social and built fabric, involving major technical knowledge and interventions that were not allowed by the building itself. This is far beyond the one-directional relationship among ideology, power and the design features of architectural forms suggested by authors like Markus (1993) and Kostof (2005).

What was striking about the case of Weronika is that she refused to move from her apartment despite the fact that it did meet her housing needs, and she did have the financial means for relocation. Although her main job is in Warsaw, this interviewee chose to commute from Gdańsk in order to keep her Wrzeszcz flat. In the interview, Weronika pointed that 'this apartment has its own charm. I prefer this type of housing ... I like the historical significance that it projects'. There were also a number of households who refused to move from the study districts despite the poor state of repair of their homes. Natasza, whose apartment was 'literally falling apart', still wanted to stay in it even though moving would have been a more affordable option: 'we have grown roots here'. Both interviewees stressed that their residential environments were providing a kind of 'shelter', both physically and emotionally, from the rapidity of socio-economic change experienced by Gdańsk and Poland in the post-Communist period.

I would argue that these examples point to a second type of associative link between households and buildings: a subjective bond that allows, as pointed out by Csikszentmihalyi and Rochberg Halton (1981) the material features of the built environment 'to represent, at least potentially, the endogenous being of the owner' while constituting an 'ecology of signs that reflects as well as shapes the pattern of the owner's self' (page 17). This transitivity reaches above economic relations or residential functions, pointing to a deeper, affective connection. Indeed, as pointed out by Wise (2000), 'what makes home-territories different from other territories is on the one hand the living of the territory (a temporalization of the space), and on the other their connection with identity, or rather a process of identification, of articulation of affect' (page 299).

Perhaps the concept of 'appropriation', as understood, for example, by Lefebvre (2001) can provide a useful explanatory framework for understanding such relations. In a way, it can be claimed that cases like Weronika and Natasza's provide evidence of a relationally fluid appropriation process between households and the built environment of their homes, since the buildings radiate meanings and associations that affect the residential mobility behaviours of their occupants, and warrant the creation of new heterogeneous networks. This connection may also be related to the 
buildings' functional blankness, since it is precisely the new set of messages which residential buildings convey in the post-socialist context that allows for the affective networks to be formed around them.

A further associative link between buildings and households in the post-Communist period exists in the case of technical networks for energy supply within the built fabric of the home. One of the most marked effects of the transition on the everyday lives of Polish households has been evident in the domain of heating systems and practices. As a result of the restructuring of energy operations, electricity, gas and district heating tariffs - formerly subsidised by the state - have been rapidly increased over the last 20 years (for a further discussion, see Buzar, 2007). The interviews indicated that energy infrastructures are now able to shape everyday life by virtue of their positionality and structure in the built fabric. This is because they affect domestic energy expenditure, and the ability of households to switch to a different heating system.

The lack of thermal insulation (or inability to introduce it due to technical or legal limitations), inadequate heating systems, as well as the mismatch between daily occupancy needs and heating regimes often had a dramatic effect on some of our interviewees' energy expenditures and quality of life. This was particularly true in large parts of Nowy Port and some buildings in Wrzesczcz, where buildings are equipped with coal stoves and not connected to the gas or district heating networks. The households who found the stoves too inconvenient to impractical to use has no option but to rely on electric heating, which is one of the most expensive sources of energy. This problem was also present in the buildings whose inhabitants were unable to connect their heating systems to existing gas installations:

'even though we heat the water with gas, we still use electricity and coal for heating, which raises the costs a lot ... we can't afford installing gas pipes and stoves' (Wilhelm).

Conversely, households who used gas for heating - or were able to switch to it from other fuels - were in a relatively favourable position. This is evidenced by Wojciech's case: his household replaced the old coal stoves with gas-fired central heating in the early 1990 s, managing to bring down its energy costs by more than $30 \%$. Also, one of the key advantages of prefabricated panel housing lies in the fact that the majority of such buildings are connected to gas, district heating and hot water networks, which may significantly reduce a household's energy costs. Natasza, who lived in a tworoom flat in a prefabricated panel estate in Nowy Port, felt that her heating bills were brought down by the availability of district heat - one of the more affordable ways of domestic warmth - as well as the fact that she and her husband had extensively improved the wall and window insulation four years ago, after the birth of their daughter. Similarly, Wiola, who relied on district heating, thought that this was a very comfortable and affordable arrangement, given her and her husband's old age and limited financial means.

It also transpired that the architectural configurations of the buildings often prevented the introduction of new heating systems into the home simply by virtue of the structural rigidity of their technological frame. In this case, the lack of interpretive flexibility limited the range of networks and associations that the buildings could 
create, in order to ensure their continued viability and survival. According to Norbert, the specific structural features of prefabricated panel buildings - the blocks 'are very long, they sometimes run for kilometres' - heavily influenced the type of modifications that could be undertaken in apartments contained within them, since the networked infrastructure inside the buildings (heating, gas, electricity, water, sewage) was also organised in a specific way. In particular, district heating ${ }^{3}$ systems in such buildings followed vertical, rather than horizontal pipes, thus preventing the installation of individual energy consumption meters for each flat (which were not necessary under Communism because district heating was subsidised).

It is interesting to note that interviewees supplemented the absence or rigidity of heating systems by introducing new, more flexible technical networks into the home. In some cases, households had installed storage heaters with thermostats, which allowed them 'to regulate the heat levels in each room individually, and to use offpeak electricity' (Nestor). This was of particular benefit to pensioners, who spend a large part of the day at home, while living in apartments of above average size that require expenditures on domestic warmth (Buzar and Czepczynski, 2008). Some interviewees had minimised their energy costs by using mobile electric heaters that allowed for heating only those rooms that were used more frequently: 'we don't heat the kitchen and bathroom at all' (Wislaw); 'we keep the kitchen cold in order to minimise costs' (Waleria). This is yet another example of how the functional blankness of buildings had effectively led to the introduction of new socio-technical devices into the home, leading to a new set of relations between household structures and heating systems.

To summarise, the post-Communist transition added a new layer of demands on the technological frame of the built stock of the two neighbourhoods, placing it in a new set of circumstances that forced buildings to create new heterogeneous alliances and networks. The consequent translation process affirmed the ability of the built fabric to act over social dynamics at the household scale, and the lived experience of the urban more generally: as a result of constraints on incomes and the housing market, livelihoods became deeply affected by extent to which buildings could be flexibly transformed to suit housing needs and host non-market economic practices, the establishment of relations of affective appropriation relations between some individuals and their residential dwellings, as well as the buildings' response to the households' energy consumption practices and requirements. The existence of these connections points to the importance of buildings as active agents in the articulation of household decisions and behaviours. Rather than acting as a rigid container for the flows of materials and ideas, seen in such a way the built environment of the home becomes a fluid vessel of multiple socio-technical networks, which, coupled with the agentic capabilities of households, help 'nurse' the geographies of everyday life.

\section{Conclusion}

In the novel Gridiron by Philip Kerr, a skyscraper kills off its designers in imaginative ways with the aid of 'sentient technologies'. While I would hesitate to ascribe such a degree of intentionality to architectural formations, it is with little

\footnotetext{
${ }^{3}$ Large-scale district heating networks are a specific legacy of Communist planning. These structures burn coal, fuel oil or natural gas in combined-heat-and-power or heat-only-boiler plants, in order to produce hot water. This is then transported through pipeline networks to collective or individual apartment buildings in entire neighbourhoods, in addition to public buildings and industrial plants.
} 
doubt that the life stories, housing biographies and residential arrangements of Nowy Port and Wrzeszcz residents reflect the rich co-expressions of agency between households and buildings in the given context. I would argue that such 'practices' of architecture are additional to the power vested in buildings by their designers. They act like building events that grow out of the creation and performance of heterogeneous networks between residential dwellings, on the one hand, and, inter alia, households, city planners, governing authorities and building materials, on the other. In a broader sense, such relations allow for the establishment of a relation of transitivity (Law, 2000) between human and non-human actants, through which the socio-spatial adaptability of the domestic environment becomes a dynamic, heterogeneous process.

The ability of the surveyed residential buildings in the districts of Nowy Port and Wrzeszcz Dolny to survive several major changes of policy and regulation regimes through time stems from the interpretive flexibility of their technological frame. In every moment when the buildings were placed in a new set of political and economic circumstances, they managed to create a new set of allies. In the post-World War II period, massive migratory movements, conditions of housing shortage, and the subsequent internal modification of the buildings in accordance with housing needs and restrictions on residential mobility ensured their viability and survival. The buildings continued to thrive during the post-Communist transition, thanks to processes of urban commodification and gentrification, coupled with the emotional attachment of many residents to them, as well as the intensification of alternative economic practices in this type of housing stock. However, the transition also made it obvious that interpretive flexibility has its own limits, especially when it comes to the structural rigidity of heating systems. The inability of household requirements and the socio-technical structures of the buildings to always successfully 'resonate' in tune with each other started to undermine the ability of the latter to outlast their technological frame.

Underpinning all such building events is the fact that the agency of built structures and configurations can only be realised through networked flows of interaction. It is the functional blankness that buildings have in relation to household needs and movements that gives them the ability to shape everyday life, rather than their original form and location per se. Thus, building events are simultaneously constituted by the spacing and timing of everyday practices, on the one hand, and the agency of buildings that govern household behaviour, on the other. This view of social action can be traced to theoretical frameworks developed by authors like Foucault and Deleuze, because it suggests that power is 'an immanent force which constitutes its own organization' (Allen, 2003, page 9) rather than a tangible form of agency that resides in physical objects, or may flow from point to point. Co-extensive 'diagrams of power' become crucial for understanding such connections, because the 'interweaving of relationships does not take place 'from above' ... but through the relationships produced within the various contexts and settings' (ibid, page 69).

It is through the articulation of household tactics in response to the 'functional blankness' of built structures, I would argue, that the networked power of architectural formations becomes possible. If we accept Gardiner's (2000) view that 'tactic' is something that 'insinuates itself into the other's place, fragmentarily, without taking it over in its entirety, without being able to keep it at a distance' (ibid, 
page 173), it is possible to see how affective appropriations of the built environment allow disadvantaged households - for example in Nowy Port, where possibilities for physical mobility in space are limited - to build a empowered relationship with their everyday space, without having to rely on financial or other material assets to improve their quality of life. The realisation of this relation is impossible without a thorough re-casting of the power of buildings. In a way, it can be said that although built structures are strategically constructed in space, it is their interaction with household tactics that allows social spaces to appropriated through time.

The reviewed evidence also corroborates some of the key principles of ANT, by showing that agency emerges 'from the interaction between symbolic systems and localized practices of meaning generation' (Murdoch, 2006, page 8) between social, built and technical networks, thus creating an 'agonistic' interface between heterogeneous actants that allows the built formations of the home to be 'folded', 'pleated' and 'ruptured' through a 'lattice of relations' (Serres, 1995, page 111). However, the challenge of linking everyday life, buildings, and people under a common conceptual umbrella has yet to enter the mainstream of ANT, although this framework is in an optimal methodological position to uncover the multiple ways in which different types of agency in the built environment are mutually enrolled and translated into relational webs.

To summarise, then, this paper has aimed to provide an initial attempt at identifying some of the conditions and forces that enable the joint construction and expression of socio-spatial agency at the households/buildings nexus. It has also tried to develop an operationalisation of the building event in the given context, using a range of STS concepts. I would emphasise that its empirical conclusions challenge the 'purification' (Latour, 1993) process that has created the definitional distinction between built and social environments, since they point to the fact that social action is constituted and performed through the relations and networks that exist between then. Thus, and given how intimately bound the destinies of people and buildings are, it may not be very helpful to think of the built environment of the home as a distinct, passive and bounded entity. It is hoped that future research and policy agendas will pay closer attention to the investigation of such issues. 
Figure 1: Location of study areas (1=Wrzeszcz Dolny, $2=$ Nowy Port), and age/typology of housing stock in Gdańsk. Source: Grabkowska, 2006; Buzar and Grabkowska, 2008.

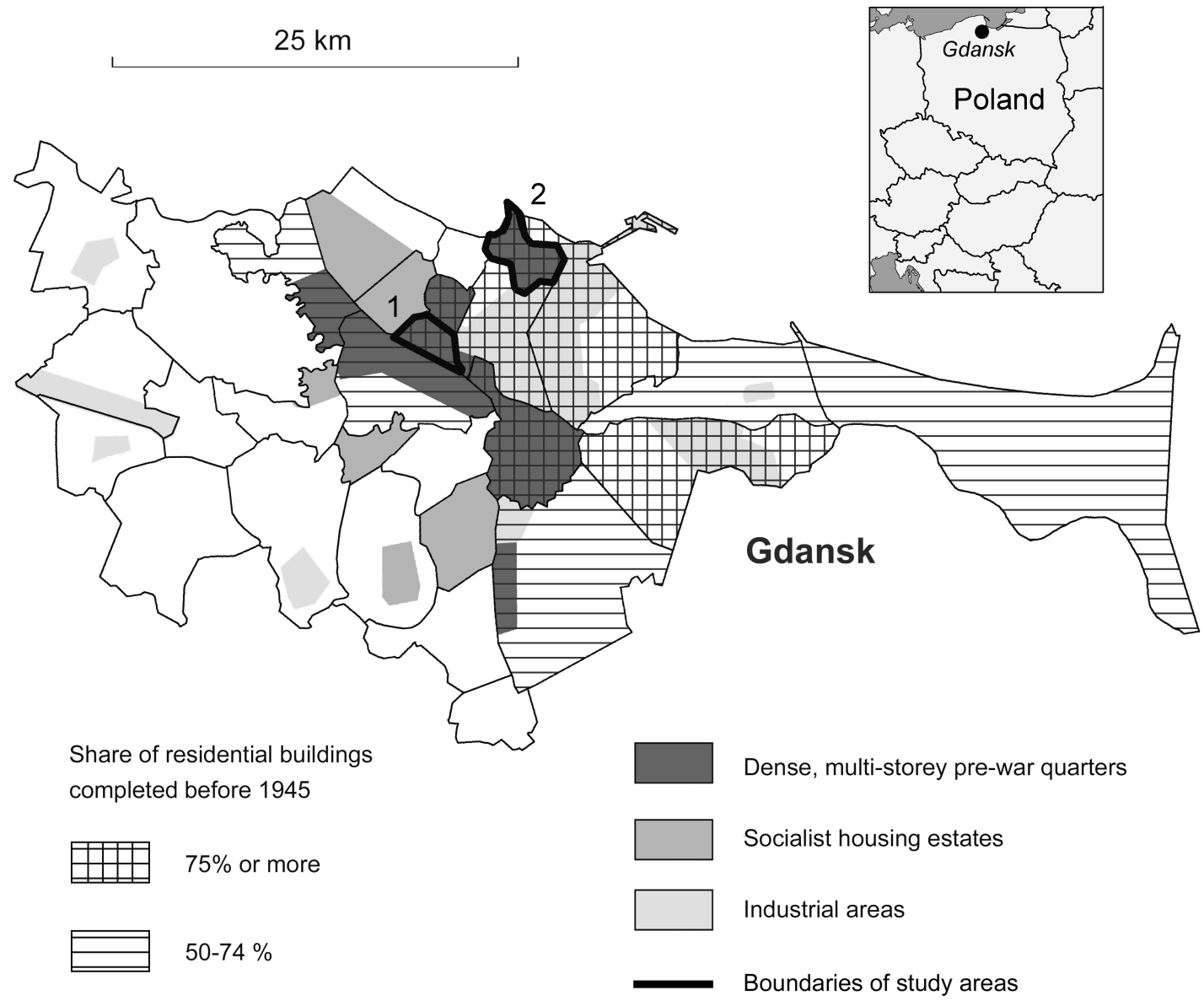

(high resolution file available) 


\section{References:}

Allen J, 2003 Lost Geographies of Power (Blackwell, Oxford)

Allen J, Massey D, Pryke M. 1999, “Introduction”, in Unsettling Cities Eds J Allen, D Massey, M Pryke (Routledge, London) pp 1-6

Amin A, Thrift N, 2002 Cities (Polity, Cambridge)

Bennett J, 2005, "The agency of assemblages and the North American blackout" Public Culture 17 445-465

Bijker W, 1993, "Do not despair: there is life after constructivism” Science, Technology and Human Values 18 113-138

Bijker W E. 1987, "The social construction of bakelite: toward a theory of invention", in The Social Construction of Technological Systems Eds W E Bijker, T P Hughes, T J Pinch (MIT Press, Cambridge, M.A.) pp 159-187

Bingham N, 1996, "Object-ions: from technological determinism towards geographies of relations" Environment and Planning D: Society and Space 14 635-657

Bourdieu P, 1989, “Social space and symbolic power” Social Theory 7 14-25

Bourdieu P, 1990 The Logic of Practice (Polity, Cambridge)

Boyer C, 1986 Dreaming the Rational City: The Myth of American City Planning (MIT Press, Cambridge, Mass.)

Brown S D, Capdevilla R. 1999, "Perpetuum mobile: substance, force and the sociology of translation", in Actor Network Theory and After Eds J Law, J Hassard (Blackwell, Oxford) pp 26-50

Buzar S, 2007 Energy Poverty in Eastern Europe: Hidden Geographies of Deprivation (Ashgate, Aldershot)

Buzar S, Czepczynski M, 2008, "Powerful domesticities: the everyday lives of elderly single women in Ljubljana and Gdańsk" Unpublished paper

Buzar S, Grabkowska M, 2008, "Flexibility and its others: diverse articulations of residential mobility in two Polish working-class districts" Unpublished paper

Callon M. 1986, "The sociology of an actor-network: the case of the electric vehicle", in Mapping the Dynamics of Science and Technology: Sociology of Science in the Real World Eds M Callon, J Law, A Rip (Macmillan, Basingstoke) pp 19-34

Callon M, Latour B. 1981, "Unscrewing the big Leviathan: how actors macro-structure reality and how sociologists help them to do so", in Advances in Social Theory and Methodology Eds K Knorr-Cetina, A V Cicourel (Routledge \& Kegan Paul, London) pp 277-303 
Csikszentmihalyi M, Rochberg-Halton E, 1981 The Meaning of Things: Domestic Symbols and the Self (Cambridge University Press, Cambridge and New York)

de Certeau M, 1984 The Practice of Everyday Life (University of California Press, Los Angeles)

Deleuze G, Guattari F, 1988 A Thousand Plataeus: Capitalism and Schizophrenia (Athlone Press, London)

Doel M, 2000 Poststructuralist Geographies: The Diabolical Art of Spatial Science (Edinburgh University Press, Edinburgh)

Dovey K, 1999 Framing Places: Mediating Power in Built Form (Routledge, New York)

Eisenman P. 1992, “Unfolding events”, in Incorporations Eds J Crary, S Kwinter (Zone, New York) pp 423-427

Foucault M, 1977 Discipline and Punish: the Birth of the Prison (Allen Lane, London)

Frisby D, 2001 Cityscapes of Modernity: Critical Explorations (Polity, Cambridge)

Gardiner M, 2000 Critiques of Everyday Life (Routledge, London)

Giddens A, 1984 The Constitution of Society: Outline of a Theory of Structuration (Polity, Cambridge)

Goss J, 1988, "The built environment and social theory: towards an architectural geography" The Professional Geographer $\mathbf{4 0}$ 392-403

Grabkowska M, 2006, "Old inner-city districts as spaces of residential flexibility: evidence from Gdańsk" Unpublished paper

Graham S, Marvin S, 2001 Splintering Urbanism: Networked Infrastructures,. Technological Mobilities, and the Urban Condition (Routledge, London and New York)

Haynen H, 2001 Architecture and Modernity (MIT Press, Cambridge, Mass)

Hetherington K, 1997, "Museum topology and the will to connect" Journal of Material Culture 2 199-218

Hetherington K, Law J, 2000, "Theme issue: after networks" Environment and Planning D: Society and Space 18 127-132

Hetherington K, Lee N, 2000, "Social order and the blank figure" Environment and Planning D: Society and Space 18 169-184

Hinchliffe S. 2000, "Entangled humans: specifying powers and their spatialities", in Entanglements of Power: Geographies of Domination/Resistance Eds J P Sharp, P Routledge, C Philo, R Paddison (Routledge, London and New York) pp 219-237 
Imrie R, 2003, “Architects' conceptions of the human body” Environment and Planning D: Society and Space 21 47-65

Jacobs J M, 2006, “A geography of big things “ Cultural Geographies 13 1-27

Jacobs J M, Smith S, 2008, "Living room: rematerialising home” Environment and Planning A $40515-519$

Jenkins L, 2002, "Geography and architecture: 11, Rue du Conservatoire and the permeability of buildings" Space and Culture 5 222-236

Jensen O B, 2007, "On the fluid production of meaning and identity: urban mobility as meaningful everyday life practice" paper presented at the Annual Meeting of the Association of American Geographers, San Francisco, 17-21st April 2007

Kaczmarek S, 2001 Rewitalizacja Terenów Poprzemysłowych. Nowy Wymiar w Rozwoju Miasta (Wydawnictwo Uniwersytetu Łódzkiego, Łódź)

King R, 1996 Emancipating Space (Guilford, New York)

Koolhaas R. 1998, "Liquid architecture”, in Anyhow Ed. C Davidson (MIT Press, Cambridge) pp 94-95

Kostof S, 2005 The City Assembled: The Elements of Urban Form Through History (Thames and Hudson, London)

Kotus J, 2006, "Changes in the spatial structure of a large Polish city - The case of Poznań" Cities 23 364-381

Kwinter S, 2001 Architectures of Time: Toward a Theory of the Event in Modernist Culture (MIT Press, Cambridge)

Latham A, McCormack D P, 2004, "Moving cities: rethinking the materialities of urban geographies" Progress in Human Geography 28 701-724

Latour B, 1998, "On Actor Network Theory: a few clarifications" http://www.nettime.org/Lists-Archives/nettime-1-9801/msg00019.html. Accessed on 14th February, 2008

Latour B. 1999, “On recalling ANT”, in Actor Network Theory and After Eds J Law, J Hassard (Blackwell, Oxford) pp 15-25

Latour B, 2005 Reassembling the Social: An Introduction to Actor-Network-Theory (Oxford University Press, Oxford)

Law J, 1992, "Notes on the theory of the actor network: ordering, strategy, heterogeneity" Systems Practice 5 379-393

Law J, Bijker W E. 1992, “Postscript: technology, stability, and social theory”, in Shaping 
Technology/Building Society: Studies in Sociotechnical Change Eds J Law, W E Bijker (MIT Press, Cambridge, Mass.) pp 291-308

Lawrence D L, Setha L M, 1990, "The built environment and spatial form" Annual Review of Anthropology 19 453-505

Lees L, 2001, "Towards a critical geography of architecture: the case of an ersatz colosseum" Ecumene 8 51-86

Lefebvre H, 2001 The Production of Space (Blackwell, Oxford)

Leyden K M, 2003, "Social capital and the built environment: the importance of walkable neighborhoods" American Journal of Public Health 93 1546-1551

Llewellyn M, 2003, "Polyvocalism and the public: 'doing' a critical historical geography of architecture" Area 35 264-271

Llewellyn M, 2004, “'Urban village' or 'white house': envisioned spaces, experienced places, and everyday life at Kensal House, London, in the 1930s" Environment and Planning D: Society and Space 22 229-249

Lorimer H, 2005, "Cultural geography: the busyness of being "more-than-representational"" Progress in Human Geography 29 83-94

Mann M, 1993 The Sources of Social Power, Vol. II: The Rise of Classes and Nation States, 1760-1914 (Cambridge University Press, Cambridge)

Markus T A, 1993 Buildings and Power: Freedom and Control in the Origin of Modern Building Types (Routledge, London)

Mayo S K, Stein J I, 1995, "Housing and labour market distortions in Poland: linkages and policy implications" Journal of Housing Economics 4 153-182

Merriman P, Revill G, Cresswell T, Lorimer H, Matless D, Rose G, et al., in press, "Landscape, mobility and practice" Social and Cultural Geography

Michalski T, 2006 The Geographical Aspects of the Transformation Process in Central and East-Central Europe (Bernardinum, Gdynia-Pelplin)

Murdoch J, 1998, “The spaces of actor-network theory” Geoforum 29 357-374

Murdoch J, 2006 Post-structuralist Geography: A Guide to Relational Space (Sage, London)

Muzioł-Węcławowicz A. 2000, "Social housing in Polish housing system”, in Social Housing in Europe Ed. M Lux (Institute of Sociology, Academy of Sciences of the Czech Republic, Prague) pp 22-48

Osborne T, Rose N, 1999, "Governing cities: notes on the spatialisation of virtue" Environment and Planning D: Society and Space 17 737-760 
Ozaki R, Lewis J R, 2006, "Boundaries and the meaning of social space: a study of Japanese house plans" Environment and Planning D: Society and Space 24 91-104

Pullman P, 2007 His Dark Materials: The Subtle Knife (Scholastic, London)

Rada Miasta Gdańska, 2005 Studium Uwarunkowań i Kierunków Zagospodarowania Przestrzennego Miasta Gdańska (Rada Miasta Gdańska, Gdańsk)

Seigworth G, 2000, "Banality for cultural studies” Cultural Studies 14 227-268

Serres M, 1995 The Natural Contract (The University of Michigan Press, Ann Arbor, MI)

Sharp J P, Routledge P, Philo C, Paddison R. 2000, "Entanglements of power: geographies of domination/resistance", in Entanglements of Power: Geographies of Domination/Resistance Eds J P Sharp, P Routledge, C Philo, R Paddison (Routledge, London and New York) pp 1-42

Sheringham M. 1996, "City space, mental space, poetic space”, in Parisian Fields Ed. M Sheringham (Reaktion Books, London) pp 85-114

Smith R G, 2003, "Baudrillard's nonrepresentational theory: burn the signs and journey without maps" Environment and Planning D: Society and Space 21 67-84

Solà-Morales I. 1998, "Liquid architecture", in Anyhow Ed. C Davidson (MIT Press, Cambridge) pp 36-43

Sommer R, 1983 Social Design: Creating Buildings with People in Mind (Prentice Hall, Englewood Cliffs, N.J.)

Thrift N. 1995, “A hyperactive world”, in Geographies of Global Change Eds R J Johnston, P J Taylor, M J Watts (Blackwell, Oxford) pp 18-35

Thrift N, 1996 Spatial Formations (Routledge, London)

Tölle A, 2008, “City profile. Gdańsk” Cities 25 107-119

Tschumi B. 2000, "Six concepts", in Architecturally Speaking: Practices of Art, Architecture, and the Everyday Ed. A Read (Routledge, London and New York) pp 155-176

Tschumi B, 2005 Event-Cities: Concept vs. Context vs. Content: No. 3+ (MIT Press, Cambridge, MA)

Uchman R, Adamski J. 2003, "How to meet the market rules and social goals for housing? Local government and housing in Poland ", in Housing Policy: an End or a New Beginning? Ed. M Lux (Open Society Institute, Local Government and Public Reform Initiative, Budapest) pp 118-182

Vidler A, 1992 The Architectural Uncanny: Essays in the Modern Unhomely (MIT Press, Cambridge, Mass.) 
Whatmore S, 2002 Hybrid Geographies (Sage, London)

Whitehead M, 2005, "Between the marvellous and the mundane: everyday life in the socialist city and the politics of the environment" Environment and Planning D: Society and Space 23 273-294

Wise J M, 2000, “Home: territory and identity" Cultural Studies 14 295-310 